\title{
PENGARUH UKURAN PERUSAHAAN, PROFITABILITAS, OPINI AUDIT, DAN UMUR PERUSAHAAN TERHADAP AUDIT DELAY (Studi Empiris pada Perusahaan Property dan Real Estate yang Terdaftar di Bursa Efek Indonesia pada Tahun 2012-2014)
}

\author{
Fauziyah Althaf Amani \\ Akuntansi Universitas Negeri Yogyakarta \\ fauziyahalthaf@gmail.com \\ Indarto Waluyo \\ Staf Pengajar Jurusan Pendidikan Akuntansi Universitas Negeri Yogyakarta
}

\begin{abstract}
Abstrak : Pengaruh Ukuran Perusahaan, Profitabilitas, Opini Audit, Dan Umur Perusahaan Terhadap Audit Delay (Studi Empiris Pada Perusahaan Property Dan Real Estate Yang Terdaftar Di Bursa Efek Indonesia Pada Tahun 2012-2014). Penelitian ini bertujuan untuk mengetahui pengaruh Ukuran Perusahaan, Profitabilitas, Opini Audit, dan Umur Perusahaan terhadap Audit Delay pada perusahaan property dan real estate yang terdaftar di Bursa Efek Indonesia pada tahun 2012-2014. Jenis penelitian ini adalah penelitian kausal komparatif dengan pendekatan ex post facto. Sampel diambil dengan menggunakan teknik purposive sampling berjumlah 41 perusahaan. Teknik analisis data yang digunakan adalah statistik deskriptif, uji asumsi klasik, analisis regresi linier sederhana, dan analisis regresi linier berganda. Berdasarkan hasil penelitian, menunjukkan bahwa (1) Ukuran Perusahaan berpengaruh signifikan terhadap Audit Delay, hal ini dibuktikan dengan koefisien regresi=3,118 , nilai signifikansi t sebesar $0,010<0,05$. (2) Profitabilitas berpengaruh signifikan terhadap Audit Delay, hal ini dibuktikan dengan koefisien regresi=-22,386, nilai signifikansi t sebesar $0,026<0,05$. (3) Opini Audit berpengaruh signifikan terhadap Audit Delay, hal ini dibuktikan dengan koefisien regresi $=3,407$, nilai signifikansi t sebesar $0,013<0,05$. (4) Umur Perusahaan berpengaruh signifikan terhadap Audit Delay, hal ini dibuktikan dengan koefisien regresi=-0,231, nilai signifikansi t sebesar $0,030<0,05$. (5) Ukuran Perusahaan, Profitabilitas, Opini Audit, dan Umur Perusahaan berpengaruh secara simultan terhadap Audit Delay, hal ini dibuktikan dengan nilai signifikansi F sebesar 0,002 < 0,05 . Besarnya pengaruh secara simultan ditunjukkan dengan nilai $\mathrm{R}$ square sebesar $12,9 \%$.
\end{abstract}

Kata kunci: Ukuran Perusahaan, Profitabilitas, Opini Audit, Umur Perusahaan, Audit Delay

\begin{abstract}
The Effect Of Company's Size, Profitability, Audit Opinion And Company's Age On The Audit Delay (Empirical Study In Property And Real Estate Company Listed On The Indonesia Stock Exchange In 2012-2014. This research aims to determine the effect of Company's Size, Profitability, Audit Opinion, and Company's Age on the Audit Delay in property and real estate company listed on the Indonesia Stock Exchange in 2012-2014. This research is a casual comparative research with ex post facto approach. The samples were taken by using purposive sampling technique consist of 41 companies in total. The data analysis technique used is descriptive statistics, classic assumption test, single regression analysis and multiple regression analysis. The results of the research show that (1) Company's Size has significant effect on the Audit Delay, this is evidenced by the regression coefficient $=-3.118$, $t$ significance value of $0.010<0.05$. (2) Profitability has significant effect on the Audit Delay, this is evidenced by the regression coefficient $=-22.386$, $t$ significance value of $0.026<0.05$. (3) Audit Opinion has significant effect on the Audit Delay, this is evidenced by the regression coefficient $=3.407$, $t$ significance value of $0.013<0.05$. (4) Company's Age has significant effect on the Audit Delay, this is evidenced by the regression coefficient $=-0.231$, $t$ significance value of $0.030<0.05$. (5) Company's Size, Profitability, Audit Opinion and Company's Age affect the Audit Delay simultaneously, this is evidenced by the significant value of $0.002 \mathrm{~F}<0.05$. The amount of influence simultaneously indicated by $R$-square of $12,9 \%$.
\end{abstract}

Keywords: Company's Size, Profitability, Audit Opinion, Company's Age, Audit Delay 


\section{JURNAL NOMINAL / VOLUME V NOMOR 1 / TAHUN 2016}

\section{PENDAHULUAN}

Laporan keuangan tahunan merupakan sumber informasi penting tentang kinerja dan prospek perusahaan bagi pemegang saham dan masyarakat sebagai salah satu dasar dalam pengambilan keputusan investasi. Informasi yang terdapat dalam laporan keuangan harus relevan dan handal. Dikatakan seperti itu, jika informasi tersebut diperoleh tepat pada waktunya.

Berdasarkan Keputusan Ketua Badan Pengawas Pasar Modal dan Lembaga Keuangan Nomor: KEP-346/BL/2011 Peraturan Nomor X.K.2 tentang Penyajian Laporan Keuangan menyatakan bahwa perusahaan publik yang terdaftar di Bursa Efek Indonesia wajib menyampaikan laporan keuangan tahunan kepada BAPEPAM dan Lembaga Keuangan (LK) serta mengumumkan kepada masyarakat paling lambat pada akhir bulan ketiga setelah tanggal laporan keuangan tahunan berdasarkan Standar Akuntansi Keuangan dan diaudit oleh Akuntan Publik yang terdaftar di BAPEPAM dan LK. Laporan keuangan tahunan yang diumumkan setidaknya meliputi laporan posisi keuangan (neraca), laporan laba rugi komprehensif, laporan arus kas, dan opini dari Akuntan.

Laporan keuangan tahunan berguna bagi pihak-pihak yang berkepentingan terhadap informasi laporan keuangan, seperti manajemen, investor, kreditor, dan pemerintah karena laporan keuangan suatu perusahaan memuat informasi mengenai laba yang dihasilkan oleh perusahaan, dimana hal tersebut merupakan salah satu dasar dalam pengambilan keputusan untuk membeli atau menjual kepemilikan yang dimiliki oleh investor. Jika informasi laba mengalami keterlambatan dalam penyampaiannya kepada publik maka akan menimbulkan reaksi negatif dari para pelaku pasar modal. Keterlambatan pelaporan, secara tidak langsung juga diartikan oleh investor sebagai sinyal yang buruk bagi perusahaan. Hal tersebut menunjukkan bahwa inform asi laba dari laporan keuangan yang dipublikasikan akan menyebabkan kenaikan atau penurunan harga saham perusahaan tersebut.

Laporan keuangan perusahaan yang disampaikan ke BAPEPAM harus disertai laporan audit oleh Akuntan Publik. Hal ini berarti, setelah laporan keuangan selesai disusun oleh perusahaan masih harus menjalani proses audit oleh auditor independen. Semakin panjang waktu yang dibutuhkan untuk proses audit, maka semakin besar kemungkinan bahwa perusahaan terlambat menyampaikan laporan keuangan ke BAPEPAM dan para pengguna laporan keuangan lainnya.

Pemeriksaan laporan keuangan oleh auditor independen untuk menilai kewajaran penyajian laporan keuangan membutuhkan waktu yang cukup lama, karena banyaknya transaksi yang harus diaudit, kerumitan dari transaksi, dan pengendalian internal yang 


\section{JURNAL NOMINAL / VOLUME V NOMOR 1 / TAHUN 2016}

kurang baik. Hal ini menyebabkan audit delay semakin meningkat. Perbedaan waktu antara tanggal laporan keuangan dengan tanggal opini audit dalam laporan keuangan menunjukkan tentang lamanya waktu penyelesaian audit, kondisi ini disebut sebagai audit delay.

Banyak faktor yang kemungkinan dapat mempengaruhi audit delay pada suatu perusahaan. Diantaranya adalah ukuran perusahaan, profitabilitas, opini audit, dan umur perusahaan. Ukuran perusahaan yang digunakan dalam penelitian ini diukur dengan menggunakan total assets atau jumlah kekayaan perusahaan. Faktor ukuran perusahaan merupakan salah satu faktor yang sering digunakan dalam penelitian sebelumnya. Menurut Pourali et al. (2013) ukuran perusahaan berpengaruh negatif terhadap audit delay. Hal ini terjadi karena perusahaan yang lebih besar mempunyai pengendalian internal yang lebih baik. Perusahaan yang memiliki pengendalian internal yang lebih baik akan mempermudah auditor sehingga hal ini dapat mengurangi kesalahan auditor dalam mengerjakan laporan auditnya.

Berbeda dengan penelitian yang dilakukan Novelia dan Dicky (2012), ukuran perusahaan tidak mempunyai pengaruh yang signifikan terhadap audit delay. Hasil penelitian tersebut menunjukkan bahwa besar atau kecilnya ukuran perusahaan tidak mempengaruhi lamanya audit delay karena penilaian ukuran perusahaan menggunakan total assets lebih stabil dibandingkan market value dan tingkat penjualan sehingga ukuran perusahaan tidak mempengaruhi audit delay.

Faktor kedua yang mungkin dapat mempengaruhi audit delay adalah profitabilitas. Profitabilitas merupakan kemampuan suatu perusahaan untuk memperoleh laba. Penelitian Ani Yulianti (2011) menyatakan bahwa profitabilitas tidak berpengaruh signifikan terhadap audit delay dikarenakan tuntutan dari pihak-pihak yang berkepentingan tidak terlalu besar sehingga tidak memicu perusahaan untuk mempublkasikan laporan keuangannya lebih cepat. Sedangkan penelitian yang dilakukan oleh Dewi Lestari (2010) menunjukkan bahwa profitabilitas mempengaruhi audit delay. Perusahaan yang mempunyai tingkat profitabilitas tinggi cenderung ingin segera mempublikasikannya lebih cepat karena akan mempertinggi nilai perusahaan di mata publik.

Faktor opini audit merupakan faktor yang juga dapat mempengaruhi audit delay. Opini audit adalah pendapat yang dikeluarkan auditor mengenai kewajaran laporan keuangan perusahaan, dalam semua hal material, yang didasarkan atas kesesuaian penyusunan laporan keuangan tersebut dengan prinsip akuntansi berlaku umum. Opini audit terdiri dari: pendapat wajar tanpa pengecualian (unqualified opinion), pendapat wajar tanpa pengecualian dengan 


\section{JURNAL NOMINAL / VOLUME V NOMOR 1 / TAHUN 2016}

bahasa penjelasan (unqualified opinion with explanatory language), pendapat wajar dengan pengecualian (qualified opinion), pendapat tidak wajar (adverse opinion), dan pernyataan tidak memberikan pendapat (disclaimer of opinion).

Hasil dari penelitian Malinda Dwi Apriliane (2015) menunjukkan bahwa opini audit berpengaruh signifikan terhadap audit delay. Perusahaan yang menerima pendapat qualified opinion akan mengalami audit delay yang semakin lama, hal ini disebabkan karena proses pemberian audit akan melibatkan negosiasi dengan klien serta konsultasi dengan partner audit yang lebih senior. Berbeda dengan perusahaan yang menerima pendapat unqualified opinion, audit delay cenderung lebih pendek karena perusahaan tidak akan menunda publikasi laporan keuangan yang berisi berita baik (good news).

Faktor terakhir yang diperkirakan dapat mempengaruhi audit delay adalah faktor umur perusahaan adalah lamanya perusahaan tersebut beroperasi. Hasil penelitian yang dilakukan oleh Armanto dan Mega (2014) menyebutkan umur perusahaan tidak berpengaruh terhadap audit delay. Perusahaan yang telah beroperasi lama tidak menjamin penyelesaian audit akan semakin cepat karena kompleksitas laporan keuangan. Hasil penelitian yang dilakukan oleh Novelia dan Dicky (2012) menunjukkan bahwa umur perusahaan mempengaruhi lamanya audit delay secara negatif, yaitu semakin lama umur perusahaan maka audit delay yang terjadi akan semakin kecil. Hal ini disebabkan oleh perusahaan yang memiliki umur lebih lama dinilai lebih mampu dan terampil dalam mengumpulkan, memproses, dan menghasilkan informasi pada saat diperlukan karena telah memiliki pengalaman yang cukup banyak dalam hal tersebut.

Pasar properti Asia Tenggara mengalami pertumbuhan tinggi pada tahun 2014 yang disebabkan oleh kekuatan fundamental di makro ekonomi. Negara Indonesia mengalami pertumbuhan di sektor properti yang didorong oleh pesatnya pertumbuhan kelas menengah pada tahun 2013 yang mengalami peningkatan sebesar $37 \%$ dari tahun 2004 menjadi 56,7\%. Para investor melihat hal tersebut sebagai peluang investasi yang menguntungkan. Peningkatan dana investasi langsung baik dari lokal maupun asing mencapai 30 miliar USD, hal tersebut mendorong kenaikan rata-rata harga jual lahan industri karena potensi naiknya permintaan. Adanya program MP3EI (Master Plan Percepatan dan Pengembangan Ekonomi Indonesia) merupakan program andalan pemerintah Indonesia di bidang property dan real estate, hal tersebut juga mendukung ketertarikan investor untuk menanamkan sahamnya di bidang property dan real estate. Menurut Ketua Umum Dewan Pengurus Pusat Real Estate 


\section{JURNAL NOMINAL / VOLUME V NOMOR 1 / TAHUN 2016}

Indonesia, saat ini Indonesia masih menjadi negara tujuan untuk investasi di bidang properti, dilihat dari banyaknya investor dari negara lain yang berminat menanamkan modalnya dalam bidang properti di Indonesia. Pertumbuhan di bidang property dan real estate di Indonesia semakin pesat, maka kebutuhan investor akan laporan keuangan secara tepat waktu juga semakin meningkat serta audit delay diharapkan akan semakin kecil. Berdasarkan uraian di atas, maka peneliti tertarik untuk mengambil judul penelitian mengenai "Pengaruh Ukuran Perusahaan, Profitabilitas, Opini Audit, dan Umur Perusahaan terhadap Audit Delay (Studi Empiris pada Perusahaan Property dan Real Estate yang Terdaftar di Bursa Efek Indonesia pada tahun 20122014)".

\section{METODE PENELITIAN}

Jenis Penelitian

Penelitian ini merupakan jenis penelitian kasual komparatif dengan pendekatan ex post facto.

\section{Waktu dan Tempat Penelitian}

Penelitian ini dilaksanakan pada bulan Februari sampai Juli 2016. Penelitian ini dilakukan pada perusahaan property dan real estate yang terdaftar di BEI. Data diambil melalui situs resmi BEI di www.idx.co.id.

\section{Populasi dan Sampel Penelitian}

Populasi dalam penelitian ini adalah seluruh perusahaan property dan real estate yang terdaftar di BEI pada tahun 2012-2014 sebanyak 48 perusahaan. Sampel dipilih berdasarkan metode purposive sampling dan terdapat 41 perusahaan yang memenuhi persyaratan, selama 3 tahun publikasi laporan keuangan perusahaan sehingga jumlah data yang digunakan sebanyak 123 data penelitian.

\section{Prosedur}

Data yang digunakan adalah data sekunder yang didapat dari situs resmi Bursa Efek Indonesia di www.idx.co.id dan data dari Pojok Bursa Universitas Islam Indonesia. Selain itu, data sekunder lain yang digunakan dalam penelitian ini adalah artikel, jurnal, dan literatur lainnya yang berkaitan dengan penelitian ini.

\section{Teknik Analisis Data}

\section{Data}

Data pada penelitian ini adalah data sekunder. Data diperoleh dengan metode dokumentasi.

\section{Teknik Analisis Data}

Penelitian ini menggunakan data sekunder yang diperoleh dari situs resmi Bursa Efek Indonesia. Metode analisis data yang digunakan yaitu analisis statistik deskriptif. Kemudian dengan uji asumsi klasik yaitu uji normalitas, uji autokorelasi, uji heterokedastisitas, dan uji multikolinearitas. Uji hipotesis menggunakan uji analisis regresi linier 
sederhana dan uji analisis regresi linier berganda.

HASIL

PENELITIAN

DAN

\section{PEMBAHASAN}

\section{Statistik Deskriptif}

Terdapat 41 perusahaan property dan real estate yang memenuhi purposive sampling selama 3 tahun publikasi laporan keuangan sehingga jumlah data yang digunakan berjumlah 123 data. Analisis statistik deskriptif yang disajikan dalam penelitian ini meliputi Nilai Minimum, Nilai Maximum, Mean (M), dan Standar Deviasi (SD). Berikut ini adalah hasil analisis statistik deskriptif dari data penelitian:

Tabel 1. Hasil Analisis Deskriptif

\begin{tabular}{cccccc}
\hline KET & $\mathbf{Y}$ & $\mathbf{X}_{\mathbf{1}}$ & $\mathbf{X}_{\mathbf{2}}$ & $\mathbf{X}_{\mathbf{3}}$ & $\mathbf{X}_{\mathbf{4}}$ \\
\hline Min & 30 & 598 & $-0,08$ & 0 & 8 \\
\hline Max & 351 & 37 & 0,31 & 1 & 42 \\
\hline M & 83,46 & 0,05 & 0,05 & 0,2 & 25,3 \\
\hline SD & 31,18 & 0,06 & 0,06 & 0,12 & 8,19
\end{tabular}

Sumber: Data Sekunder yang Diolah, 2016

\section{Uji Asumsi Klasik}

Uji asumsi klasik pada penelitian ini terdiri dari uji normalitas, uji autokorelasi, uji heterokedastisitas, dan uji multikolinearitas.

\section{a. Uji Normalitas}

Hasil uji normalitas dapat dilihat pada tabel dibawah ini:
Tabel 2. Hasil Uji Normalitas

\begin{tabular}{cc}
\hline Asymp. Sig & Keterangan \\
\hline $\mathbf{0 , 0 6 2}$ & Berdistribusi Normal
\end{tabular}

Sumber: Lampiran Uji Normalitas, 2016

Selain menggunakan perhitungan statistik, normalitas data dapat dilihat dengan gambar P-P Plot Normalitas, sebagai berikut:

Normal P-P Plot of Regression Standardized Residual

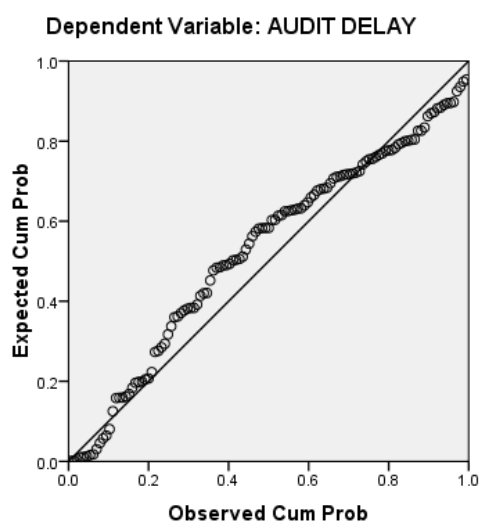

b. Uji Autokorelasi

Hasil uji autokorelasi dapat dilihat pada tabel dibawah ini:

Tabel 3. Hasil Uji Autokorelasi

\begin{tabular}{cc}
\hline Durbin-Watson & Keterangan \\
\hline $\mathbf{1 , 9 6 3}$ & Tidak terjadi \\
& autokorelasi
\end{tabular}

Sumber: Lampiran Uji Autokorelasi, 2016

Hasil pada tabel 3 menunjukkan bahwa nilai Durbin-Watson adalah 1,963 lebih besar dari nilai du 1,7733 pada tingkat signifikansi 0,05 . 


\section{JURNAL NOMINAL / VOLUME V NOMOR 1 / TAHUN 2016}

\begin{tabular}{lcc}
\hline \multirow{1}{*}{ Variabel } & \multicolumn{2}{c}{ Perhitungan } \\
\cline { 2 - 3 } & Tolerance & VIF \\
\hline Ukuran & 0,916 & 1,092 \\
Perusahaan & & \\
\hline Profitabilitas & 0,919 & 1,088 \\
\hline Opini Audit & 0,963 & 1,039 \\
\hline Umur Perusahaan & 0,972 & 1,029
\end{tabular}

\section{c. Uji Heterokedastisitas}

Hasil uji heterokedastisitas dapat dilihat

pada tabel dibawah ini:

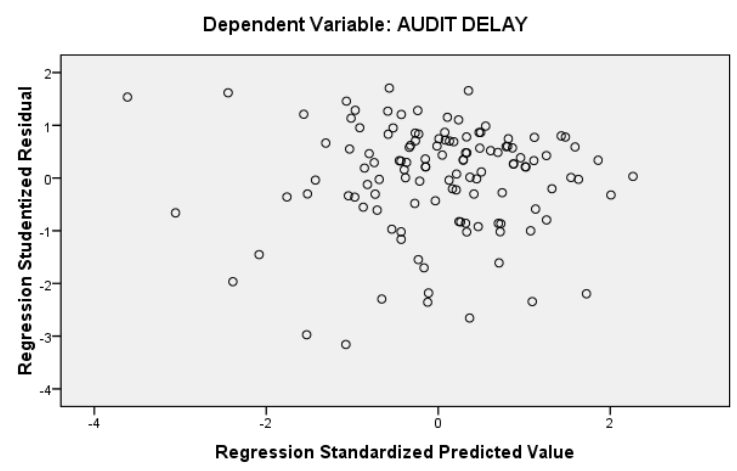

Tabel 4. Hasil Uji Heterokedastisitas

\begin{tabular}{|l|c|}
\hline \multicolumn{1}{|c|}{ Variabel } & Sig \\
\hline Ukuran Perusahaan & 0,108 \\
\hline Profitabilitas & 0,998 \\
\hline Opini Audit & 0,375 \\
\hline Umur Perusahaan & 0,108 \\
\hline
\end{tabular}

Sumber: Lampiran Uji Heterokedastisitas, 2016

Dari tabel 4 diatas, dapat dlihat bahwa semua variabel bebas mempunyai nilai probabilitas signifikansi lebih besar dari 0,05. Dengan demikian, dapat disimpulkan bahwa tidak terjadi heterokedastisitas dalam model regresi.

\section{d. Uji Multikolinearitas}

Hasil uji multikolinearitas dapat dilihat pada tabel dibawah ini:

Tabel 5. Hasil Uji Multikolinearitas

Sumber: Lampiran Uji Multikolinearitas, 2016

Berdasarkan tabel diatas, menunjukkan semua variabel bebas mempunyai nilai Tolerance $\geq 0,10$ dan nilai $\mathrm{VIF} \leq 10$. Dengan demikian, dapat disimpulkan bahwa seluruh variabel bebas dalam penelitian ini tidak terjadi multikolinieritas.

\section{Uji Hipotesis}

Pengujian hipotesis pada penelitian ini adalah dengan menggunakan analisis regresi linier sederhana dan analisis regresi linier berganda. Analisis ini digunakan untuk mengetahui pengaruh dari variabel-variabel ukuran perusahaan, profitabilitas, opini audit, dan umur perusahaan terhadap audit delay secara parsial menggunakan analisis regresi sederhana, sedangkan untuk menguji hipotesis secara simultan menggunakan analisis regresi berganda.

\section{a. Hipotesis 1}

H1: Ukuran Perusahaan berpengaruh signifikan terhadap Audit Delay pada perusahaan property dan real estate yang 


\section{JURNAL NOMINAL / VOLUME V NOMOR 1 / TAHUN 2016}

terdaftar di Bursa Efek Indonesia pada tahun 2012-2014.

Berdasarkan perhitungan regresi linier sederhana, maka persamaan garis regresi untuk hipotesis 1 adalah seperti berikut:

$$
Y=75,976-3,118 X_{1}
$$

Berdasarkan persamaan regresi tersebut, dapat dilihat nilai koefisien Ukuran Perusahaan sebesar $-3,118$ yang bernilai negatif, maka semakin tinggi ukuran perusahaan maka akan semakin rendah pula audit delay.

Uji t statistik untuk variabel Ukuran Perusahaan menunjukkan bahwa $\mathrm{t}$ hitung sebesar -2,064 dan nilai t tabel 1,657. Jika keduanya dibandingkan, maka t hitung lebih besar dari t tabel $(-2,064>1,657)$. Hal itu juga didukung dengan menghasilkan nilai signifikansi 0,010 yang berarti lebih kecil dari nilai 0,05 , yang artinya terdapat pengaruh signifikan antara variabel independen terhadap variabel dependen secara individual, sehingga dapat disimpulkan bahwa variabel audit delay dipengaruhi oleh variabel Ukuran Perusahaan. Berdasarkan hal tersebut, maka hipotesis pertama yang menyatakan bahwa terdapat pengaruh signifikan Ukuran Perusahaan terhadap audit delay diterima.

Nilai R Square sebesar 0,053 hal ini menunjukkan 5,3\% audit delay dipengaruhi oleh Ukuran Perusahaan, sedangkan sisanya sebesar $94,7 \%$ dipengaruhi oleh variabel lain di luar penelitian ini.
Hasil penelitian ini mendukung hasil penelitian yang dilakukan oleh Arifatun (2013) menunjukkan bahwa ukuran perusahaan berpengaruh negatif terhadap audit delay sehingga semakin besar ukuran perusahaan maka audit delay akan semakin kecil.

\section{b. Hipotesis 2}

H2: Profitabilitas berpengaruh signifikan terhadap Audit Delay pada perusahaan property dan real estate yang terdaftar di Bursa Efek Indonesia pada tahun 2012-2014.

Berdasarkan perhitungan regresi linier sederhana, maka persamaan garis regresi untuk hipotesis 1 adalah seperti berikut:

$$
\mathrm{Y}=\mathbf{7 6 , 9 1 2} \text { - 22,386X2 }
$$

Berdasarkan persamaan regresi tersebut, dapat dilihat nilai koefisien Profitabilitas sebesar $-22,386$ yang bernilai negatif, maka semakin tinggi Profitabilitas maka akan semakin rendah audit delay.

Uji $t$ statistik untuk variabel Profitabilitas menunjukkan bahwa t hitung sebesar -2,257 dan nilai t tabel 1,657. Jika keduanya dibandingkan, maka $t$ hitung lebih besar dari t tabel $(-2,257>1,657)$. Hal itu juga didukung dengan menghasilkan nilai signifikansi 0,026 yang berarti lebih kecil dari nilai 0,05 , yang artinya terdapat pengaruh signifikan antara variabel independen terhadap variabel dependen secara individual, sehingga dapat 


\section{JURNAL NOMINAL / VOLUME V NOMOR 1 / TAHUN 2016}

disimpulkan bahwa variabel audit delay dipengaruhi oleh variabel Profitabilitas. Berdasarkan hal tersebut, maka hipotesis kedua yang menyatakan bahwa terdapat pengaruh signifikan Profitabilitas terhadap audit delay diterima.

Nilai R Square sebesar 0,040 hal ini menunjukkan $4 \%$ audit delay dipengaruhi oleh Profitabilitas, sedangkan sisanya sebesar 96\% dipengaruhi oleh variabel lain di luar penelitian ini.

Hasil penelitian Fitria Ingga Saemargani (2015) mendukung hasil penelitian ini dengan menunjukkan bahwa profitabilitas berpengaruh signifikan terhadap audit delay. Perusahaan yang memperoleh good news cenderung akan lebih tepat waktu dalam penyampaian laporan keuangannya dibandingkan dengan perusahaan yang memperoleh bad news.

\section{c. Hipotesis 3}

H3: Opini Audit berpengaruh signifikan terhadap Audit Delay pada perusahaan property dan real estate yang terdaftar di Bursa Efek Indonesia pada tahun 2012-2014.

Berdasarkan perhitungan regresi linier sederhana, maka persamaan garis regresi untuk hipotesis 1 adalah seperti berikut:

$$
Y=73,843+3,407 X_{3}
$$

Berdasarkan persamaan regresi tersebut, dapat dilihat nilai koefisien Opini Audit sebesar 3,407 yang bernilai positif, maka semakin tinggi Opini Audit maka akan semakin tinggi audit delay.

Uji t statistik untuk variabel Opini Audit menunjukkan bahwa t hitung sebesar 2,514 dan nilai t tabel 1,657 . Jika keduanya dibandingkan, maka t hitung lebih besar dari t tabel $(2,514>1,657)$. Hal itu juga didukung dengan menghasilkan nilai signifikansi 0,013 yang berarti lebih kecil dari nilai 0,05 , yang artinya terdapat pengaruh signifikan antara variabel independen terhadap variabel dependen secara individual, sehingga dapat disimpulkan bahwa variabel audit delay dipengaruhi oleh variabel Opini Audit. Berdasarkan hal tersebut, maka hipotesis ketiga yang menyatakan bahwa terdapat pengaruh signifikan Opini Audit terhadap audit delay diterima.

Nilai R Square sebesar 0,050 hal ini menunjukkan $0,5 \%$ audit delay dipengaruhi oleh Opini Audit, sedangkan sisanya sebesar 95\% dipengaruhi oleh variabel lain di luar penelitian ini.

Hasil penelitian ini konsisten dengan teori yang dikemukakan oleh Carslaw dan Kaplan dalam Jeane Deart Meity Prabandari dan Rustiana (2007) yang menemukan adanya hubungan antara Opini Audit dengan audit delay. Pada perusahaan yang menerima jenis pendapat qualified opinion akan menunjukkan audit delay yang lebih panjang dibandingkan dengan perusahaan yang menerima pendapat unqualified opinion. 


\section{JURNAL NOMINAL / VOLUME V NOMOR 1 / TAHUN 2016}

\section{d. Hipotesis 4}

H4: Umur Perusahaan berpengaruh signifikan terhadap Audit Delay pada perusahaan property dan real estate yang terdaftar di Bursa Efek Indonesia pada tahun 2012-2014.

Berdasarkan perhitungan regresi linier sederhana, maka persamaan garis regresi untuk hipotesis 1 adalah seperti berikut:

$$
\mathrm{Y}=\mathbf{8 0 , 7 8 2}-\mathbf{0 , 2 3 1 \mathrm { X } _ { 4 }}
$$

Berdasarkan persamaan regresi tersebut, dapat dilihat nilai koefisien Umur Perusahaan sebesar $-0,231$ yang bernilai negatif, maka semakin tinggi Umur Perusahaan maka akan semakin rendah audit delay.

Uji t statistik untuk variabel Umur Perusahaan menunjukkan bahwa t hitung sebesar -2,194 dan nilai t tabel 1,657. Jika keduanya dibandingkan, maka t hitung lebih besar dari t tabel $(-2,194>1,657)$. Hal itu juga didukung dengan menghasilkan nilai signifikansi 0,030 yang berarti lebih kecil dari nilai 0,05 , yang artinya terdapat pengaruh signifikan antara variabel independen terhadap variabel dependen secara individual, sehingga dapat disimpulkan bahwa variabel audit delay dipengaruhi oleh variabel Umur Perusahaan. Berdasarkan hal tersebut, maka hipotesis keempat yang menyatakan bahwa terdapat pengaruh signifikan Umur Perusahaan terhadap audit delay diterima.
Nilai R Square sebesar 0,038 hal ini menunjukkan $3,8 \%$ audit delay dipengaruhi oleh Umur Perusahaan, sedangkan sisanya sebesar 96,2\% dipengaruhi oleh variabel lain di luar penelitian ini.

Penelitian ini sejalan dengan penelitian yang dilakukan oleh Novelia Sagita Indra dan Dicky Arisudhana (2012) yang menyatakan bahwa Umur Perusahaan berpengaruh negatif terhadap audit delay yang artinya bahwa semakin lama Umur Perusahaan maka audit delay akan semakin singkat.

\section{e. Hipotesis 5}

H5: Ukuran Perusahaan, Profitabilitas, Opini Audit, dan Umur Perusahaan berpengaruh secara bersama-sama terhadap Audit Delay pada perusahaan property dan real estate yang terdaftar di Bursa Efek Indonesia pada tahun 2012-2014.

Untuk menguji H5 dilakukan dengan analisis regresi linier berganda. Hasil perhitungan dapat dilihat pada tabel di bawah ini:

Tabel 6. Hasil Perhitungan Hipotesis 5

\begin{tabular}{ll}
\hline \multicolumn{1}{c}{ Variabel } & \multicolumn{1}{c}{ Koefisien Regresi } \\
\hline Konstanta & 80,490 \\
\hline Ukuran & $-2,196$ \\
Perusahaan & \\
\hline Profitabilitas & $-13,807$ \\
\hline Opini Audit & 2,581 \\
\hline Umur & $-0,176$ \\
Perusahaan &
\end{tabular}




\section{JURNAL NOMINAL / VOLUME V NOMOR 1 / TAHUN 2016}

\begin{tabular}{ll}
\hline R Square & 0,129 \\
\hline F hitung & 4,372 \\
\hline F tabel & 2,45 \\
\hline Sig F & 0,002
\end{tabular}

Sumber: Hasil Olah Data Regresi Linier Berganda, 2016

Berdasarkan perhitungan regresi linier sederhana yang ditunjukkan tabel di atas, maka persamaan garis regresi untuk hipotesis 5 adalah seperti berikut:

$$
\begin{gathered}
Y=80,490-2,196 X_{1}-13,807 X_{2}+ \\
2,581 X_{3}-0_{176} X_{4}
\end{gathered}
$$

Berdasarkan persamaan regresi tersebut, dapat disimpulkan bahwa variabel Ukuran Perusahaan memberikan nilai koefisien -2,196, variabel Profitabilitas memberikan nilai koefisien $-13,807$, variabel Opini Audit memberikan nilai koefisien 2,581 dan variabel Umur Perusahaan memberikan nilai koefisien $-0,176$.

Uji F statistik untuk variabel independensi menghasilkan nilai $\mathrm{F}$ hitung sebesar 4,372. Jika dibandingkan dengan nilai $\mathrm{F}$ tabel pada tingkat signifikansi $5 \%$ yaitu sebesar 2,45 (Df 1=4 dan Df $2=118$ ), maka nilai $\mathrm{F}$ hitung lebih besar daripada $\mathrm{F}$ tabel $(4,372>2,45)$. Hal ini juga didukung dengan nilai signifikansi 0,002 yang berarti lebih kecil dari nilai 0,05 , sehingga dapat disimpulkan bahwa variabel audit delay dipengaruhi oleh variabel Ukuran Perusahaan, Profitabilitas, Opini Audit, dan Umur Perusahaan. Sehingga hipotesis kelima yang menyatakan bahwa terdapat pengaruh Ukuran Perusahaan, Profitabilitas, Opini Audit, dan Umur Perusahaan secara simultan terhadap Audit Delay diterima.

Nilai R Square sebesar 0,129 hal ini menunjukkan $12,9 \%$ Audit Delay dipengaruhi oleh Ukuran Perusahaan, Profitabilitas, Opini Audit, dan Umur Perusahaan secara simultan, sedangkan sisanya sebesar $87,1 \%$ dipengaruhi oleh variabel lain di luar penelitian ini.

\section{SIMPULAN DAN SARAN}

\section{Simpulan}

a. Ukuran Perusahaan berpengaruh secara signifikan terhadap Audit Delay pada perusahaan property dan real estate yang terdaftar di Bursa Efek Indonesia pada tahun 2012-2014. Hal ini ditunjukkan dengan koefisien regresi=3,118 , nilai signifikansi t sebesar 0,010 yang lebih kecil dari 0,05. Dari hasil analisis data diperoleh $R$ Square $\left(\mathrm{R}^{2}\right)$ sebesar 0,053 yang berarti Audit Delay pada perusahaan property dan real estate yang terdaftar di Bursa Efek Indonesia pada tahun 2012-2014 dipengaruhi oleh Ukuran Perusahaan sebesar 5,3\%.

b. Profitabilitas berpengaruh secara signifikan terhadap Audit Delay pada perusahaan property dan real estate yang terdaftar di Bursa Efek Indonesia pada tahun 2012-2014. Hal ini ditunjukkan dengan koefisien regresi=- 


\section{JURNAL NOMINAL / VOLUME V NOMOR 1 / TAHUN 2016}

22,386, nilai signifikansi $\mathrm{t}$ sebesar sebesar 0,026 yang lebih kecil dari 0,05. Dari hasil analisis data diperoleh $R$ Square $\left(\mathrm{R}^{2}\right)$ sebesar 0,040 yang berarti Audit Delay pada perusahaan property dan real estate yang terdaftar di Bursa Efek Indonesia pada tahun 2012-2014 dipengaruhi oleh Profitabilitas sebesar $4 \%$.

c. Opini Audit berpengaruh secara signifikan terhadap Audit Delay pada perusahaan property dan real estate yang terdaftar di Bursa Efek Indonesia pada tahun 2012-2014. Hal ini ditunjukkan dengan koefisien regresi $=3,407$, nilai signifikansi $\mathrm{t}$ sebesar 0,013 yang lebih kecil dari 0,05. Dari hasil analisis data diperoleh $R$ Square $\left(\mathrm{R}^{2}\right)$ sebesar 0,050 yang berarti Audit Delay pada perusahaan property dan real estate yang terdaftar di Bursa Efek Indonesia pada tahun 2012-2014 dipengaruhi oleh Opini Audit sebesar $5 \%$.

d. Umur Perusahaan berpengaruh secara signifikan terhadap Audit Delay pada perusahaan property dan real estate yang terdaftar di Bursa Efek Indonesia pada tahun 2012-2014. Hal ini ditunjukkan dengan koefisien regresi=0,231 , nilai signifikansi t sebesar oleh sig sebesar 0,038 yang lebih kecil dari 0,05. Dari hasil analisis data diperoleh $R$ Square $\left(\mathrm{R}^{2}\right)$ sebesar 0,038 yang berarti
Audit Delay pada perusahaan property dan real estate yang terdaftar di Bursa Efek Indonesia pada tahun 2012-2014 dipengaruhi oleh Umur Perusahaan sebesar $3,8 \%$.

e. Terdapat pengaruh Ukuran Perusahaan, Profitabilitas, Opini Audit, dan Umur Perusahaan secara simultan terhadap Audit Delay pada perusahaan property dan real estate yang terdaftar di Bursa Efek Indonesia pada tahun 2012-2014. Hal ini ditunjukkan oleh sig sebesar 0,002 yang lebih kecil dari 0,05. Dari hasil analisis data diperoleh $R$ Square sebesar 0,129 yang berarti Audit Delay pada perusahaan property dan real estate yang terdaftar di Bursa Efek Indonesia pada tahun 2012-2014 dipengaruhi secara simultan oleh Ukuran Perusahaan, Profitabilitas, Opini Audit, dan Umur Perusahaan sebesar 12,9\%.

\section{Saran}

Berdasarkan kesimpulan dan hasil penelitian yang telah dikemukakan diatas, maka saran-saran yang diajukan adalah:

1. Bagi Auditor

Hasil penelitian ini dapat memberikan informasi mengenai rata-rata Audit Delay pada perusahaan property dan real estate yang terdaftar di Bursa Efek Indonesia pada tahun 2012-2014, serta faktor-faktor yang mempengaruhinya sehingga para 


\section{JURNAL NOMINAL / VOLUME V NOMOR 1 / TAHUN 2016}

auditor dapat mengendalikan faktorfaktor dominan yang mempengaruhi Audit Delay. Dari hasil penelitian ini, faktor yang paling dominan adalah Ukuran Perusahaan dan Opini Audit. Auditor disarankan untuk merencanakan pekerjaan lapangan dengan baik agar proses audit dapat dilaksanakan secara efektif dan efisien sehingga Audit Delay dapat ditekan seminimal mungkin dan laporan keuangan dapat dipublikasikan tepat waktu.

2. Bagi Perusahaan

Perusahaan sebaiknya terus bekerja secara profesional dan melakukan evaluasi berkala terhadap kinerja tiap-tiap divisi perusahaan agar dapat mengendalikan faktor-faktor dominan yang mempengaruhi lamanya Audit Delay. Didalam perikatan kontrak, perusahaan disarankan melakukan penunjukkan kepada auditor sebelum tanggal penutupan tahun buku agar dapat segera melakukan pekerjaan lapangan. Perusahaan diharapkan dapat memberikan data-data yang diperlukan selama proses pemeriksaan sehingga laporan keuangan auditan dapat dipublikasikan lebih awal.

3. Bagi Penelitian Selanjutnya

Sebaiknya peneliti selanjutnya dapat melakukan penelitian yang sama untuk jenis industri yang lain agar diperoleh sampel yang lebih besar, sehingga dapat memperkuat hasil kesimpulan yang telah dilakukan oleh peneliti-peneliti terdahulu. Begitu juga untuk variabel bebas yang digunakan sebagai prediktor sebaiknya ditambah dengan menggunakan lebih banyak variasi variabel lain seperti internal audit, solvabilitas, komite audit, dan lainnya yang dapat digunakan untuk menguji Audit Delay.

\section{DAFTAR PUSTAKA}

Ani Yulianti. (2011). Faktor-faktor yang Berpengaruh terhadap Audit Delay (Studi Empiris pada Perusahaan yang Terdaftar di Bursa Efek Indonesia Tahun 2007-2008). Skripsi. Yogyakarta: Universitas Negeri Yogyakarta.

Arens, Alvin A., Randal J. Elder, dan Mark S. Beasley. (2006). Auditing dan Jasa Assurance: Pendekatan Terintegrasi. Jakarta: Erlangga.

Arifatun P.S. (2013). Pengaruh Ukuran Perusahaan, Profitabilitas Perusahaan, Ukuran Auditor, dan Opini Audit terhadap Audit Delay (Studi Empiris pada Perusahaan Makanan dan Minuman yang Terdaftar di Bursa Efek Indonesia Periode 2009-2011). Skripsi. Yogyakarta: Universitas Negeri Yogyakarta.

Armanto Witjaksono dan Mega Silvia. (2014). Analisis Faktor-faktor yang Berpengaruh terhadap Audit Delay pada Perusahaan Consumer Goods yang Terdaftar di Bursa Efek Indonesia Periode 2010-2013. Jurnal Akuntansi. Jakarta: Universitas Bina Nusantara.

BAPEPAM. (2011). Keputusan Ketua Badan Pengawas Pasar Modal dan Lembaga Keuangan Nomor: KEP- 
346/BL/2011 tentang Penyampaian Laporan Keuangan Berkala Emiten atau Perusahaan Publik dapat diakses http://www.martinaberto.co.id/downl oad/Peraturan_Bapepam/X.K.2_Pen yampaian_Laporan_Keuangan_Berk ala_Emiten_atau_Perusahaan_Publik .pdf. pada tanggal 5 Maret 2016 jam 23.32 .

. (2012). Keputusan Ketua Badan Pengawas Pasar Modal dan Lembaga Keuangan Nomor: KEP431/BL/2012 tentang Penyampaian Laporan Tahunan Emiten atau Perusahaan Publik dapat diakses http://ptba.co.id/public/uploads/perat uran_Bapepam_dan_LK_X.K.6_1_a gustus_2012 tentang penyampaian laporan tahunan.pdf. pada tanggal 5 Maret 2016 jam 23.01.

Ashton, R. H., Willingham J. J., dan Elliot R K. (1987). An Empirical Analysis of Audit Delay. Journal of Accounting Research. (Vol. 25 No. 2). Autumn: 275-292.

Camelia Putri Purnamasari. (2012). Analisis Faktor-faktor yang Mempengaruhi Audit Delay pada Perusahaan LQ 45 yang Terdaftar di Bursa Efek Indonesia. Jurnal Akuntansi. Jakarta: Universitas Gunadarma.

Carslaw, C.A.P.N. dan Kaplan, S.E. (1991). An Examination of Audit Delay: Further Evidence from New Zealand. Accounting and Business Research (Vol. 22 No. 85). Hlm. 21-32.

Dewi Lestari. (2010). Analisis Faktor-faktor yang Mempengaruhi Audit Delay: Studi Empiris pada Perusahaan Consumer Goods yang Terdaftar di Bursa Efek Indonesia. Skripsi. Semarang: Universitas Diponegoro.

Esynasali Violetta Sebayang. (2014). Analisis Faktor-faktor yang Mempengaruhi Audit Delay (Studi Empiris pada Perusahaan Consumer
Goods yang Terdaftar di Bursa Efek Indonesia. Skripsi. Semarang: Universitas Diponegoro.

Fitria Ingga Saemargani. (2015). Pengaruh Ukuran Perusahaan, Umur Perusahaan, Profitabilitas Perusahaan, Solvabilitas Perusahaan, Ukuran KAP, dan Opini Auditor terhadap Audit Delay (Studi Kasus pada Perusahaan LQ 45 yang Terdaftar di Bursa Efek Indonesia Tahun 2011-2013). Skripsi. Yogyakarta: Universitas Negeri Yogyakarta.

Haryono Jusup. (2001). Auditing (Pengauditan) Buku I. Yogyakarta: Sekolah Tinggi Ilmu Ekonomi YKPN.

Hesti Candra Sari. (2011). Analisis Faktorfaktor yang Berpengaruh terhadap Jangka Waktu Penyelesaian Audit (Kajian Empiris pada Perusahaan Manufaktur yang Terdaftar di Bursa Efek Indonesia Tahun 2008-2009). Skripsi. Semarang: Universitas Diponegoro.

Ikatan Akuntan Indonesia. (2009). Pernyataan Standar Akuntansi Keuangan No. 1 (Revisi 2009) tentang Penyajian Laporan Keuangan dapat diakses https://staff.blog.ui.ac.id/martani/file s/2011/04/ED-PSAK-1.pdf. pada tanggal 9 Maret 2016 jam 16.32. . (2013) Pernyataan Standar Akuntansi Keuangan No. 1 (Revisi 2013) tentang Penyajian Laporan Keuangan dapat diakses https://staff.blog.ui.ac.id/martani/file s/2011/04/ED_PSAK_1_2013-2013JULI-23.pdf. pada tanggal 9 Maret 2016 jam 16.45.

Imam Ghozali. (2011). Ekonometrika. Semarang: Badan Penerbit Universitas Diponegoro. 


\section{JURNAL NOMINAL / VOLUME V NOMOR 1 / TAHUN 2016}

(2011). Aplikasi Analisis Multivariate dengan Program IBM SPSS 19. Semarang: Badan Penerbit Universitas Diponegoro.

Imam Subekti. (2005). Faktor-faktor yang Berpengaruh terhadap Audit Delay di Indonesia. Jurnal Ekonomi dan Manajemen (Vol. 6 No. 1). Hlm. 4754.

Indriantoro N. dan Supeno B. (2009). Metode Penelitian Bisnis untuk Akuntansi dan Manajemen. Yogyakarta: BPFE Yogyakarta.

Jogiyanto Hartono. (2010). Teori Portofolio dan Analisis Investasi. Edisi Ketujuh. Yogyakarta: BPFE.

Jumratul Haryani dan I Dewa Nyoman Wiratmaja. (2014). Pengaruh Ukuran Perusahaan, Komite Audit, Penerapan International Financial Reporting Standards dan Kepemilikan Publik pada Audit Delay. E-jurnal Akuntansi Universitas Udayana 6.1 (2014):6378. Bali: Universitas Udayana.

Kasmir. (2008). Bank dan Lembaga Keuangan Lainnya. Jakarta: Raja Grafindo.

Malinda Dwi Apriliane. (2015). Analisis Faktor-faktor yang Mempengaruhi Audit Delay (Studi Empiris pada Perusahaan Pertambangan yang Terdaftar di Bursa Efek Indonesia Tahun 2008-2013). Skripsi. Yogyakarta: Universitas Negeri Yogyakarta.

Menteri Keuangan. (2002). Keputusan Menteri Keuangan Republik Indonesia Nomor: 423/KMK.06/2002 tentang Jasa Akuntan Publik dapat diakses http://www.dayamandiri.co.id/image s/upload/File/KMK-423-2002.pdf. pada tanggal 21 Maret 2016 jam 23.32.
Modugu, Prince Kennedy. (2012). Determinants of Audit Delay in Nigerian Companies: Empirical Evidence. Research Journal of Finance and Accounting (Vol. 3 No. 6). Hlm. 46-54.

Mulyadi. (2002). Auditing. Jakarta: Salemba Empat.

Novelia Sagita Indra dan Dicky Arisudhana. (2012). Faktor-faktor yang Mempengaruhi Audit Delay pada Perusahaan Go Public di Indonesia (Studi Empiris pada Perusahaan Property di Bursa Efek Indonesia Tahun 2007-2010). Jurnal Fakultas Ekonomi Budi Luhur (Vol. 1 No. 2 Oktober 2012). Jakarta: Universitas Budi Luhur.

Pourali, M. R., Jozi, M., Rostami K. H., Taherpour G. R., dan Niazi F. (2013). "Investigation of Effective Factors in Audit Delay: Evidence from Tehran Stock Exchange (TSE)". Research Journal of Applied Sciences, Engineering and Technology. 5(2):405-410.

Singgih Santoso. (2006). Menggunakan SPSS untuk Statistik Parametrik. Jakarta. PT Elex Media Komputindo.

Sugiyono. (2009). Metode Penelitian Kuantitatif, Kulaitatif, dan $R \& D$. Bandung: Alfabeta. . (2012). Statistik Untuk Penelitian. Bandung: Alfabeta.

Tim Penyusun. (2011). Pedoman Penulisan Tugas Akhir Jurusan Pendidikan Akuntansi. Yogyakarta: Universitas Negeri Yogyakarta.

Tri Diana Wahyu. (2014). Pengaruh Ukuran Perusahaan, Profitabilitas, Solvabilitas, Jenis Industri dan Ukuran Kantor Akuntan Publik terhadap Audit Delay (Studi Kasus pada Perusahaan Indeks LQ 45 yang Terdaftar di Bursa Efek Indonesia Tahun 2010-2013). Skripsi. 
Yogyakarta: Universitas Negeri Yogyakarta.

$\underline{\text { www.idx.co.id }}$

Yuliansari, N. (2011). Faktor-faktor yang Mempengaruhi Audit Delay di Indonesia. Tesis. Yogyakarta: Universitas Gadjah Mada.

Zaki Baridwan. (2004). Intermediate Accounting. Yogyakarta: BPFE Yogyakarta. 